$S M T D$

STRATEGIC MATERIALS TECHNOLOGY DEPARTMENT

Keywords: Resistance Welding Solid-State Welding

Stainless Steel

Retention: Permanent

\title{
DEVELOPMENT OF A SOLID-STATE RESISTANCE WELD FOR JOINING DUAL-BURST DISK ASSEMBLIES TO VESSEL BODIES (U)
}

\author{
By
}

W. R. Kanne, Jr.

\&

G. J. McKinney

\section{MASTER}

DISTRIBUTION OF THIS DOCURENT IS UNLIMITE

ISSUED: APRIL 1998

$\frac{\text { D. Themen Pani }}{\text { Authorized Derivative Classifier }}$

SRTC SAVANNAH RIVER TECHNOLOGY CENTER, AIKEN, SC 29808 Westinghouse Savannah River Company

Prepared for the U. S. Department of Energy under Contract DE-AC09-96SR18500 
DOCUMENT: WSRC-TR-98-00109

TITLE: DEVELOPMENT OF A SOLID-STATE RESISTANCE WELD FOR JOINING DUAL-BURST DISK ASSEMBLIES TO VESSEL BODIES (U)

APPROVALS

W. B. STanne, C

W. R. Kanne, Jr., AUTHOR

MATERIALS TECHNOLOGY SECTION

G. J. McKinney, AUTHOR

MATERIALS TECHNQLOGY SECTION<smiles>C1=CCCCCC1</smiles>

G. R. Cannell, TECHNICAL REVIEWER MATERIALS TECHNOLOGY SECTION

C. E. Sessions, MANAGER

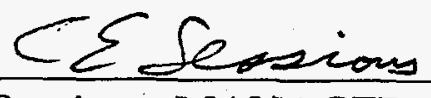

WELD ENGINEERING GROUP

D. Thome Plin:

D. T. Rankin, MANAGER

MATERIALS COMPATIBILITY \& JOINING TECHNOLOGY GROUP

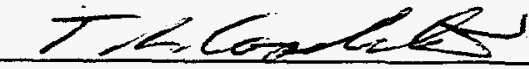

DATE:

DATE: $\quad 4 / 1 / 2 \delta$

DATE: $\quad 3 / 23 / 98$

DATE: $4-1-98$

DATE: $4 / 1 / 98$

DATE:

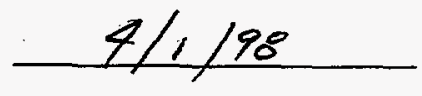

T. L. Capeletti, MANAGER

MATERIALS TECHNOLOGY SECTION 


\section{DISCLAIMER}

This report was prepared as an account of work sponsored by an agency of the United States Government. Neither the United States Government nor any agency thereof, nor any of their employees, make any warranty, express or implied, or assumes any legal liability or responsibility for the accuracy, completeness, or usefulness of any information, apparatus, product, or process disclosed, or represents that its use would not infringe privately owned rights. Reference herein to any specific commercial product, process, or service by trade name, trademark, manufacturer, or otherwise does not necessarily constitute or imply its endorsement, recommendation, or favoring by the United States Government or any agency thereof. The views and opinions of authors expressed herein do not necessarily state or reflect those of the United States Government or any agency thereof. 


\section{DISCLAIMER}

Portions of this document may be illegible electronic image products. Images are produced from the best avaliable original document. 


\title{
DEVELOPMENT OF A SOLID-STATE RESISTANCE WELD FOR JOINING DUAL-BURST DISK ASSEMBLIES TO VESSEL BODIES
}

\author{
By \\ W. R. Kanne, Jr. \\ \& \\ G. J. McKinney
}

\section{INTRODUCTION}

The objective of this program was to develop a solid-state resistance plug weld for installation of dual-burst disk assemblies in a set of tritium storage vessels. This is a cooperative effort with the Los Alamos National Laboratory (LANL), Ref. 1. Los Alamos designed the vessels and also designed and supplied ten pairs of test parts for development. Following development of the weld, a set of about eight vessels will be fabricated for tritium storage tests. These tests will demonstrate functioning of the dualburst disk assembly in addition to demonstrating long term compatibility of the plug weld for tritium service.

Initially, the vessels were designed for loading and storage at Los Alamos. The design was later changed to accommodate loading and storage at the Savannah River Site (SRS). During the time the components for the storage vessels were being made at Los Alamos, a new large resistance welder was installed in the production facility at the Allied Signal Kansas City Plant (AS-KCP). Welding of the disk assemblies into the components for storage and attachment of the stems to these components was originally planned for Savannah River. With the availability of the Kansas City production welder, the disk assemblies and stems will be installed at the Kansas City Plant.

The dual-burst disk plug weld is very similar to welds successfully used for many years. Stem attachment (reclamation) welds, Ref. 2 are used for tritium containment and have the same configuration as the dual-burst disk plug welds. The stem attachment welds are 0.250 inch diameter and are therefore much smaller than the 2.0 inch diameter dual-burst disk plug welds. The dual-burst disk plug weld is also very similar to the much larger (5.0 inch diameter) plug weld used to seal defense waste canisters, Ref. 3-5. Both these welds have a very successful history in production at Savannah River, indicating that solid-state resistance plug welding is a very robust process. 


\section{SUMMARY}

This development program determined welding conditions for joining dual-burst disk assemblies (pucks) to vessel bodies. Weld parameters, joint design, and the interference between the puck and body were determined using development parts supplied by the Los Alamos National Laboratory. An diametrical interference of 0.020 inch between the puck and the body was chosen to minimize distortion of the disks. Corresponding welding parameters were 12,000 pounds force and 65,000 amperes current applied for one second. The strength of the welds was measured on a tensile machine by forcing the pucks out of the bodies. Metallography was used to confirm bond quality. During welding of the disks, the maximum temperature of the chamber wall below the weld was about $100^{\circ} \mathrm{C}$.

\section{ADVANTAGES OF SOLID-STATE RESISTANCE WELDING}

Resistance welding has significant advantages compared to fusion welding for the DualBurst Disk application. These are outlined below. More detail on these advantages can be found in Ref. 6.

Advantages specific to this application:

- Low heat input from the welding operation

- Minimum deformation of the disk and vessel

Advantages for general production applications:

- Higher weld strength

- Fast and reliable process

- Low maintenance equipment

- Less dependence on material composition and microstructure

- Elimination of fusion weld defects

\section{STORAGE VESSEL DESIGN}

The dual-burst disk storage vessel as initially designed is shown in Fig. 1. The vessel is made from forged 304L stainless steel. Changes to the design were made to accommodate loading at SRS (rather than LANL). Modifications made by Chad Sweeney of EES are shown in Figure 2. These changes include a standard counterbore on each end for attachment of tubes of the type used on production reservoirs and threaded holes on each end to accommodate production fixturing for pinch welding. Stems of type 421804-00 are available for attachment to the storage vessel bodies. Components of the puck assembly are shown in Figure 3. Loading of these vessels at SRS will use existing $1 \mathrm{H}$ fixturing. 


\section{IMPLEMENTATION PLAN FOR STORAGE VESSELS}

The following sequence of steps is currently underway to fabricate the dual-burst disk storage vessels shown in Figure 1 with the modifications shown in Figure 2:

1) SRS: Develop process for plug welds

2) LANL: Machine parts, clean parts, weld large disk and extender to puck

3) AS-KCP: Weld pucks into caps, weld stems to each cap

4) LANL: Laser weld small disks into pucks, GTA weld caps together, radiograph

5) SRS: Proof and leak test assemblies, load with tritium, perform baseline tests (function test, burst test, metallography)

6) SRS: Storage followed by 5,10 , and 15 year tests

\section{DEVELOPMENT OF WELDING PROCESS}

Test pieces representative of the storage vessel were supplied by Los Alamos for development of the welding process. Design of these test pieces, representative of the shell-half that contains the puck, is shown in Figure 4. Prior to welding these test pieces, six simple plug weld parts were welded to begin to determine the best weld parameters and weld joint interference. Welds were made on the simple plug parts with 0.020 to 0.080 inch interference, 10,000 to 25,000 pounds force, and 66,200 to 72,600 amperes current.

Fixtures were designed and fabricated, Figures $5 \& 6$, for joining the pucks to the LANL test pieces. The top electrode sits on the puck and is centered by the counterbore within which the smaller disk will later be placed. The electrode is designed to not contact the walls of the vessel during welding but to cover the upset from the plug weld and thereby control expulsion. The bottom electrode simply holds the vessel body during welding. The bottom electrode sits on the slotted side of the support block. The slots are to assure removal of air from within the fixture during evacuation before welding. These same fixtures can be used for the actual storage vessels.

The main emphasis during welding of the ten sets of test pieces from LANL was determination of the effect of interference between the puck and the body upon deformation of the puck. This is shown in Table I where the column "Hole Expansion" gives the change in diameter of each of the five locations in the puck where a diameter could be measured. Measurements were made in the SRS Metrology Laboratory using equipment capable of much greater accuracy than needed for this work. At higher interference the top of the puck (side for small disk) is compressed by up to 0.002 inch and the bottom (side for large disk) expands by up to 0.008 inch. At low interference, 
each diameter is seen to expand, apparently from radial contraction during cooling after welding. The top side expands by up to 0.002 inch and the bottom side by up to 0.006 inch. A puck diameter of 2.020 to 2.022 inch was decided upon for the pucks for storage vessels, as shown in Figure 3. This results in a possible interference range of 0.017 to 0.025 inch because of the tolerance on the $\mathrm{ID}$ of the seating surface for the puck, Figure 4 .

Welding conditions for the low interference welds are:

$\begin{array}{ll}\text { Current } & 65,000 \text { Amperes } \\ \text { Force } & 12,000 \text { Pounds } \\ \text { Time } & 1 \text { second }\end{array}$

A time of one second was used for all welds. A higher force and somewhat higher current was used for higher interference welds, as can be seen in Table I. Welding parameters are monitored on a Macintosh based Lab View data acquisition system. The print-out in Figure 7 shows motion of the weld head during the weld as well as current, force, and voltage as a function of time. The one second of weld time is broken into six pulses of 10 cycles (of $60 \mathrm{Hertz}$ ) with three cool cycles between each pulse. A photograph of one of the test weld samples, as-welded, is shown in Figure 8.

\section{EVALUATION OF RESISTANCE WELDS}

The welds and the welding process were evaluated by metallography, compression tests, and temperature measurements as well as by the distortion measurements discussed above. Metallographic appearance of the welds is similar to the five-inch diameter Defense Waste plug welds and to the 0.250 inch diameter reclamation welds which are in production at Savannah River. Both these production processes have been very reliable.

A metallographic section of welds made using pucks with two different diameters (and therefore different interference) are shown in Figure 9. Both have a worked and recrystallized grain structure in the weld area. A notch present at the bottom of the weld area is typical of this type of weld. The notch has not been any problem in either reclamation welds (which also see tritium pressure) or the Defense Waste welds. At higher magnification, Figure 10, the weld interface is seen to be well bonded with grain growth across the boundary.

Compression tests were done on a large Instron machine to assess the strength of the welds. A 1.9 inch diameter bar was used to push on the underside of the puck until the puck was pushed out of the body of the test piece. During the test the test piece rested on a support ring 2.4 Inch ID and 3.13 inch OD. Best results were obtained when the top of the test piece was machined flat before the compression test. A load vs. displacement for one sample is shown in Figure 11A. This sample failed at 85,000 pounds force. During this test the puck formed a dome as if the weld had been pressure tested to failure, Figure 11B. The projected burst strength based upon the compression test results is 27,000 psi. 
Temperature measurements were made during and after the weld at 5 locations in the body and puck in each of two welds. The peak temperature at the hottest location in the chamber (at the location of the bottom of the puck extender, which was not present in these test welds) was about $100^{\circ} \mathrm{C}$ (the highest temperature on 6 thermocouples on two samples was $105^{\circ} \mathrm{C}$. A plot of the temperature vs. time for the hottest thermocouple is shown in Figure 12. Within the puck itself the temperature is much higher, reaching $190^{\circ} \mathrm{C}$ at a location 0.5 inch from the weld joint.

\section{CONCLUSIONS}

Results from this development program support the proposal that a solid-state resistance weld is an excellent method for joining the puck to the body of dual-burst disk vessels. The results provide a basis for the joint design, weld fixturing, and welding conditions for achieving the weld.

A diametrical interference of 0.020 inch was found to minimize distortion of the puck while maintaining excellent strength. Welding conditions for this interference were 12,000 pounds force and 65,000 amperes current for at weld time of one second. Welds were made in a vacuum to maximize weld strength.

Metallographic examination of the welds indicated good bonding between the two components. Mechanical push (compression) tests showed a failure force of 85,000 pounds, from which a burst strength of approximately 27,000 psi for the plug weld can be calculated. Temperature measurements during welding showed a maximum temperature in the chamber below the weld of about $100^{\circ} \mathrm{C}$.

\section{ACKNOWLEDGMENTS}

Planning and support for this work was provided by Los Alamos National Laboratory, in particular Andrew Fusco, Kristi Keffer, Charles Huff, and Robert Gates. Temperature measurements were done by Tim Smail of Equipment Engineering. Redesign of the storage vessel to accommodate loading at SRS was accomplished by Chad Sweeney of Equipment Engineering. Compression testing of the welds was done by Baker White and the Building 723-A Metallography Laboratory technicians. Metallography was done by Tina Stefęk and the Building 723-A Metallography Laboratory technicians.

\section{REFERENCES}

1. A. M. Fusco, "Development Report for Dual-Burst Disks", DOE Report No. LA13192-MS, November 1996.

2. G. J. McKinney and S. R. Howard, "Qualification of the reclamation Welding Parameters for 316 CRES Stems (U), WSRC-TR-97-00298, September 1997. 
3. B. J. Eberhard and J. W. Kelker, Jr., "High Current Resistance Welding of Nuclear Waste Containers", Welding Journal, Vol. 61, No. 6, p. 15-19, June 1982.

4. G. R. Cannell and C. E. Sessions, "Proper Procedures are the Key to Welding Radioactive Waste Containers", Welding Journal, p. 61-67, August 1997.

5. S. L. West, "Characterization of Type 304 Stainless Steel Solid-State Closure Welds for Radioactive Waste Containment", Microstructural Science, Vol. 22, M.T. Shehata, T. R. Leduc, I. LeMay, and M. R. Louthan, Jr., ed. p. 449-460, June 1995.

6. R. M. Gates, S. L. Robinson, W. R. Kanne, Jr., J. J. Straub, "Proposal for Solid-State Resistance Welding Applications: A Simple, Reliable, and Cost Efficient Method for Reservoir Fabrication", LANL Report No. ESA-WE-97-629U, August 11, 1997. 
Table I

\section{PLUG WELD DATA}

\begin{tabular}{|c|c|c|c|c|c|}
\hline $\begin{array}{l}\text { Plug } \\
\text { Number } \\
\end{array}$ & $\begin{array}{l}\text { Interfer- } \\
\text { ence (in.) }\end{array}$ & $\begin{array}{l}\text { Current/Force } \\
\text { (KA/ pounds) }\end{array}$ & $\begin{array}{l}\text { Plug } \\
\text { Ht. (in) }\end{array}$ & $\begin{array}{l}\text { Hole Expansion } \\
\text { (Top to Bot., mils) }\end{array}$ & $\underline{\text { Test - Result }}$ \\
\hline PMOD-1A-01 & 0.020 & $66.8 / 12,000^{1}$ & 0.056 & $+2 /+1 /+2 /+1 /+2$ & Met. - OK \\
\hline PMOD-1A-02 & 0.020 & $64.2 / 12,000^{2}$ & 0.053 & $+2 / 0 /+2 /+5 /+6$ & Push-85klb 3 \\
\hline PMOD-1A-03 & $.008 / .020^{4}$ & $68.2 / 12,000^{1}$ & 0.050 & $+2 /+2 /+2 /+3 /+4$ & Met. - OK \\
\hline PMOD-1A-04 & $.010 / .020^{4}$ & $68.7 / 15,000^{2}$ & 0.041 & $+1 / * * /+2 /+5 /+6$ & None \\
\hline PMOD-1A-05 & 0.040 & $79.3 / 25,000^{2}$ & 0.038 & $-2 / 0 /+1 /+5 /+6$ & Met. - OK \\
\hline PMOD-1A-06 & 0.040 & $75.5 / 25,000^{2}$ & $* *$ & $-2 /-1 /+1 /+5 /+7$ & Push-116klb \\
\hline PMOD-1A-07 & 0.030 & $74.5 / 12,000^{2}$ (hot) & 0.048 & $+1 /+4 /+2 /+4 /+6$ & Push-87klb 3 \\
\hline PMOD-1A-08 & 0.030 & $70.7 / 15,000^{2}$ & 0.049 & $0 /+1 /+2 /+5 /+8$ & Met. - OK \\
\hline PMOD-1A-09 & 0.040 & $79.0 / 25,000^{2}$ & $* *$ & $-2 / * * / * * / * * / * * / * *$ & lost in mail \\
\hline PMOD-1A-10 & 0.020 & $64.7 / 12,000^{2}$ & 0.048 & $+2 / * * / * * / * * / * * / * *$ & @ LANL \\
\hline
\end{tabular}

1. Temperatures measured during welding $\left(105^{\circ} \mathrm{C}\right.$ maximum temp. in chamber)

2. Weld made in vacuum (others welded in air)

3. Top machined flat before push test

4. Tapered counterbore

** Data not available (disks in place on $-09 \&-10$ ) 


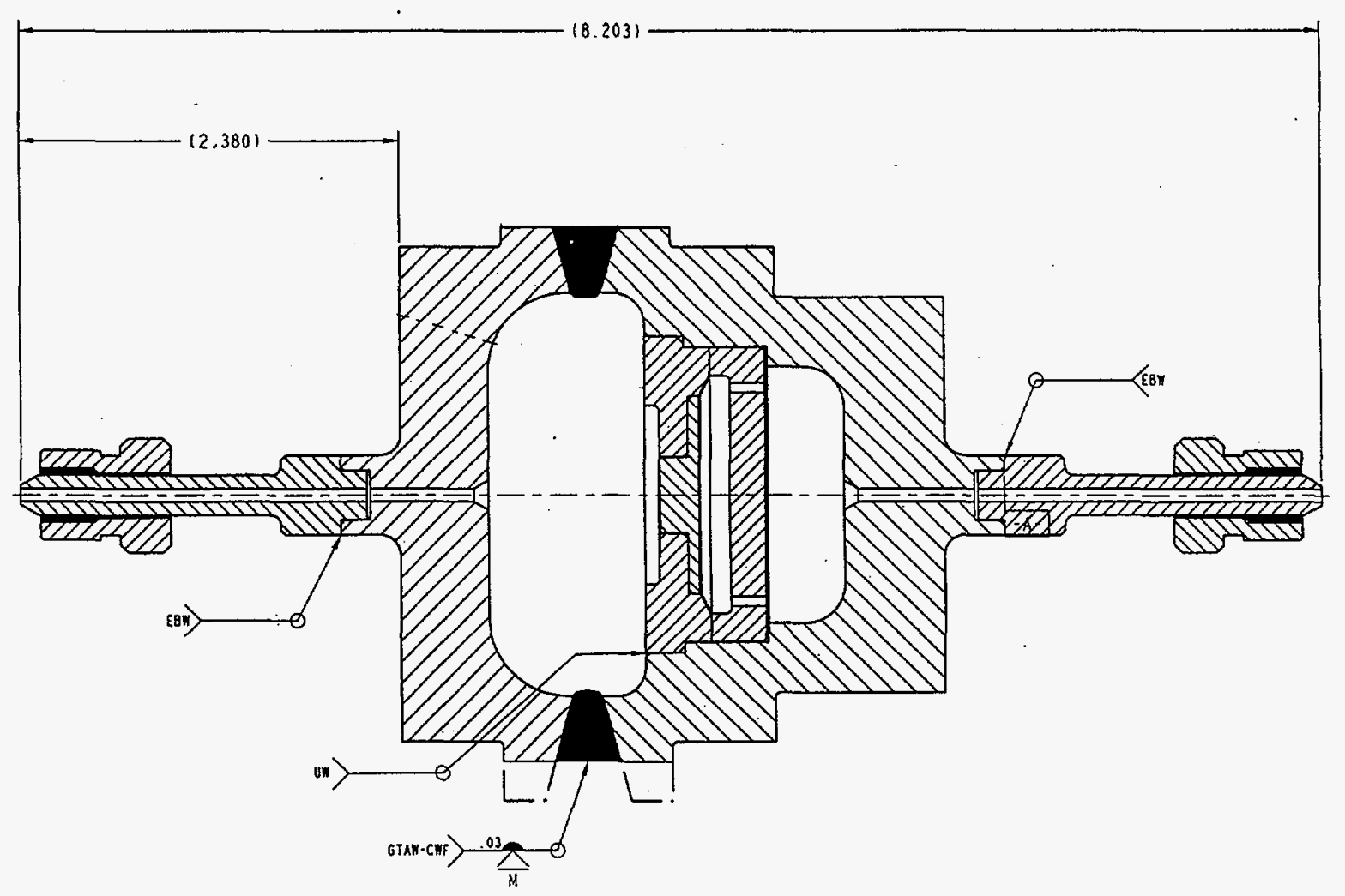

Figure 1. Dual Burst-Disk vessel design for loading at Los Alamos National Laboratory. 


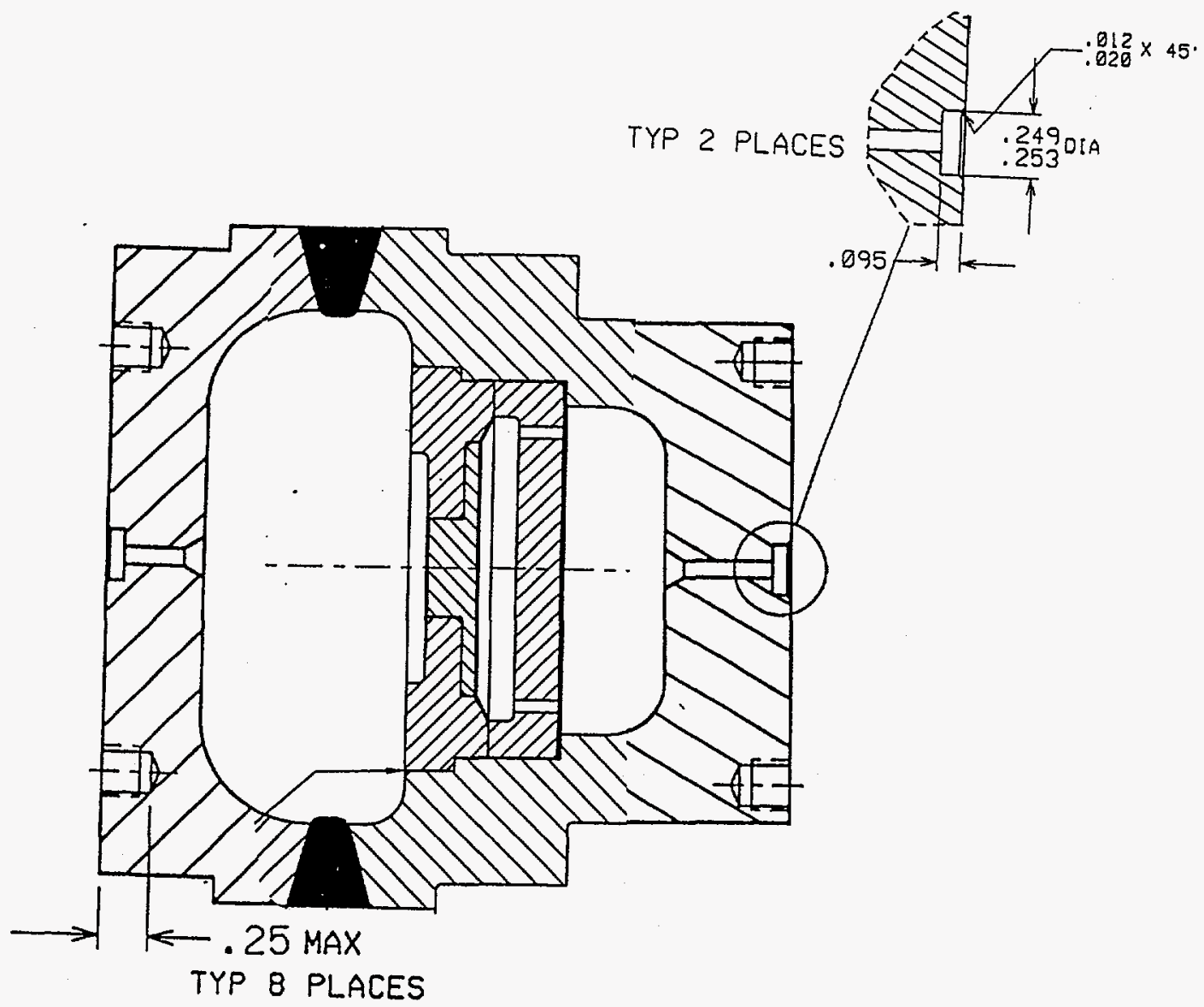

Figure 2. Design modified for loading at the Savannah River Site. Standard reclamation tubes will be welded into the counterbores on each end of the vessel. 


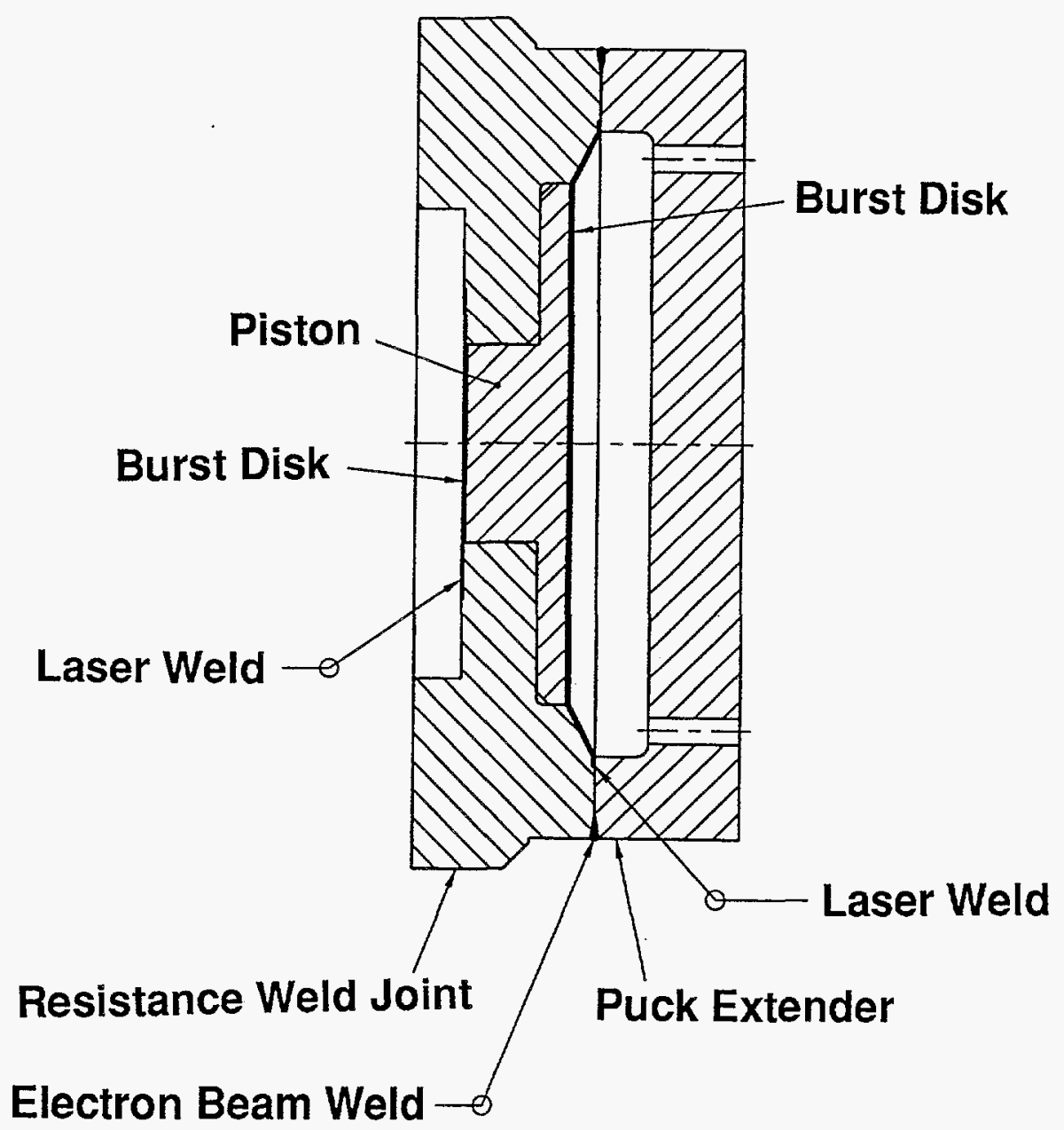

Figure 3. Puck design for storage samples. During development of the welding conditions the outside diameter of the puck was varied. The final diameter at the resistance weld joint was determined to be $2.022 / 2.020$ to provide approximately .020 diametrical interference with the counterbore into which it is welded. Puck material is 304L stainless steel. Development welds were made using pucks without the extender and without the burst disks in place. 


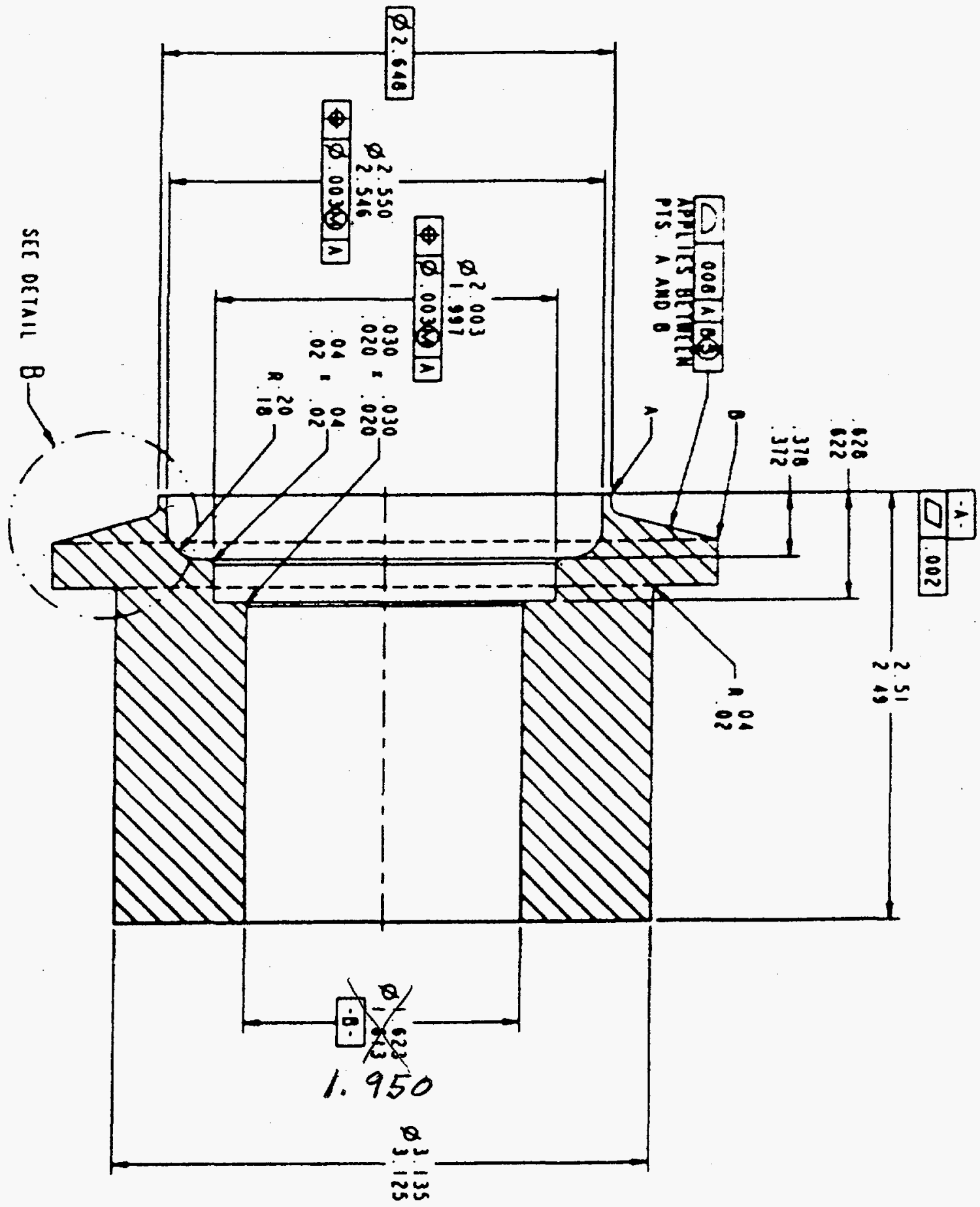

Figure 4. Test piece representative of the vessel body for the purposes of developing welding conditions for the resistance plug weld. From Los Alamos drawing ESA-WE4195-036. The overall diameter is 3.89/3.87 and the material is bar stock 304L stainless steel. 


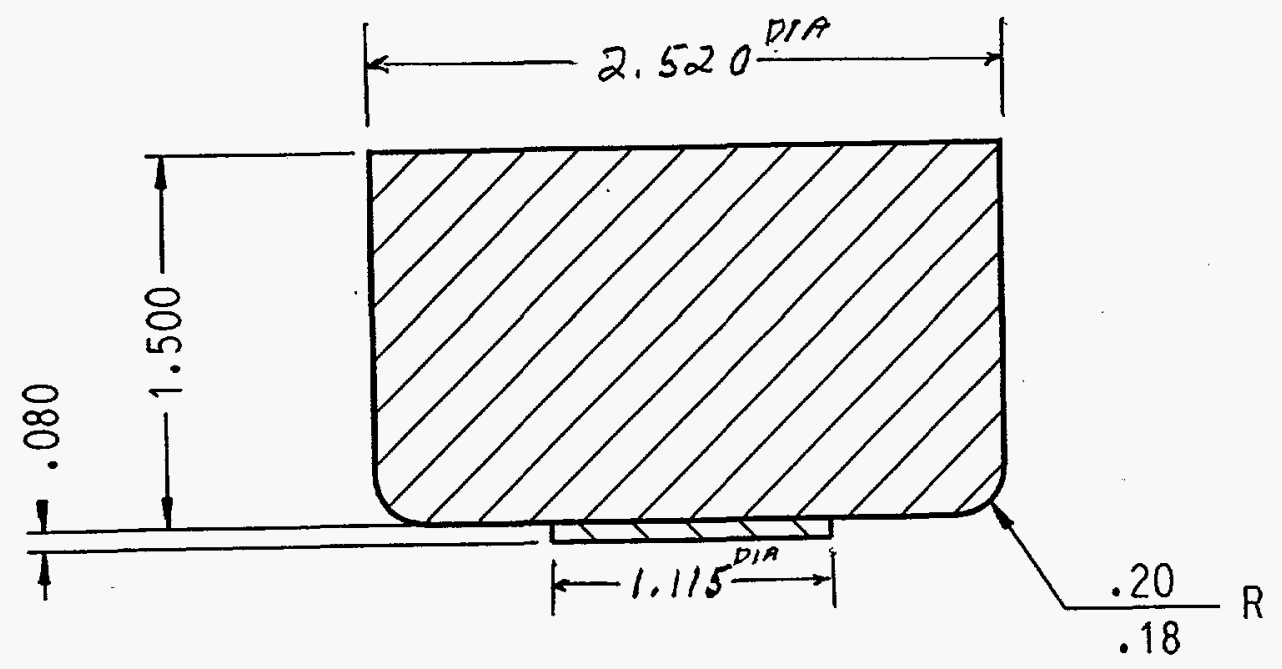

A. Top electrode, $1 \mathrm{x}$

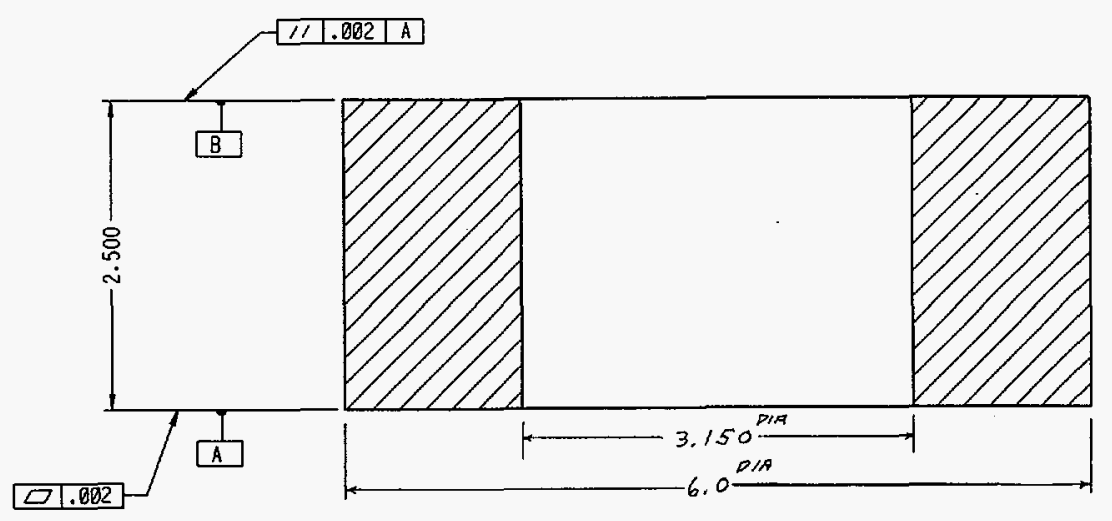

B. Bottom electrode, $0.5 \mathrm{x}$

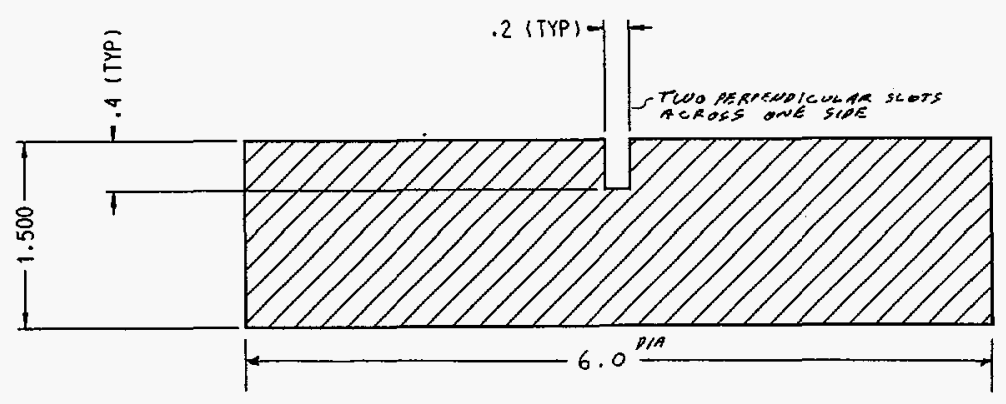

C. Support block, $0.5 \mathrm{x}$

Figure 5. Fixture design for dual-burst disk plug weld. Material is Class 2 copper. Shown are sections through cylindrical parts. 


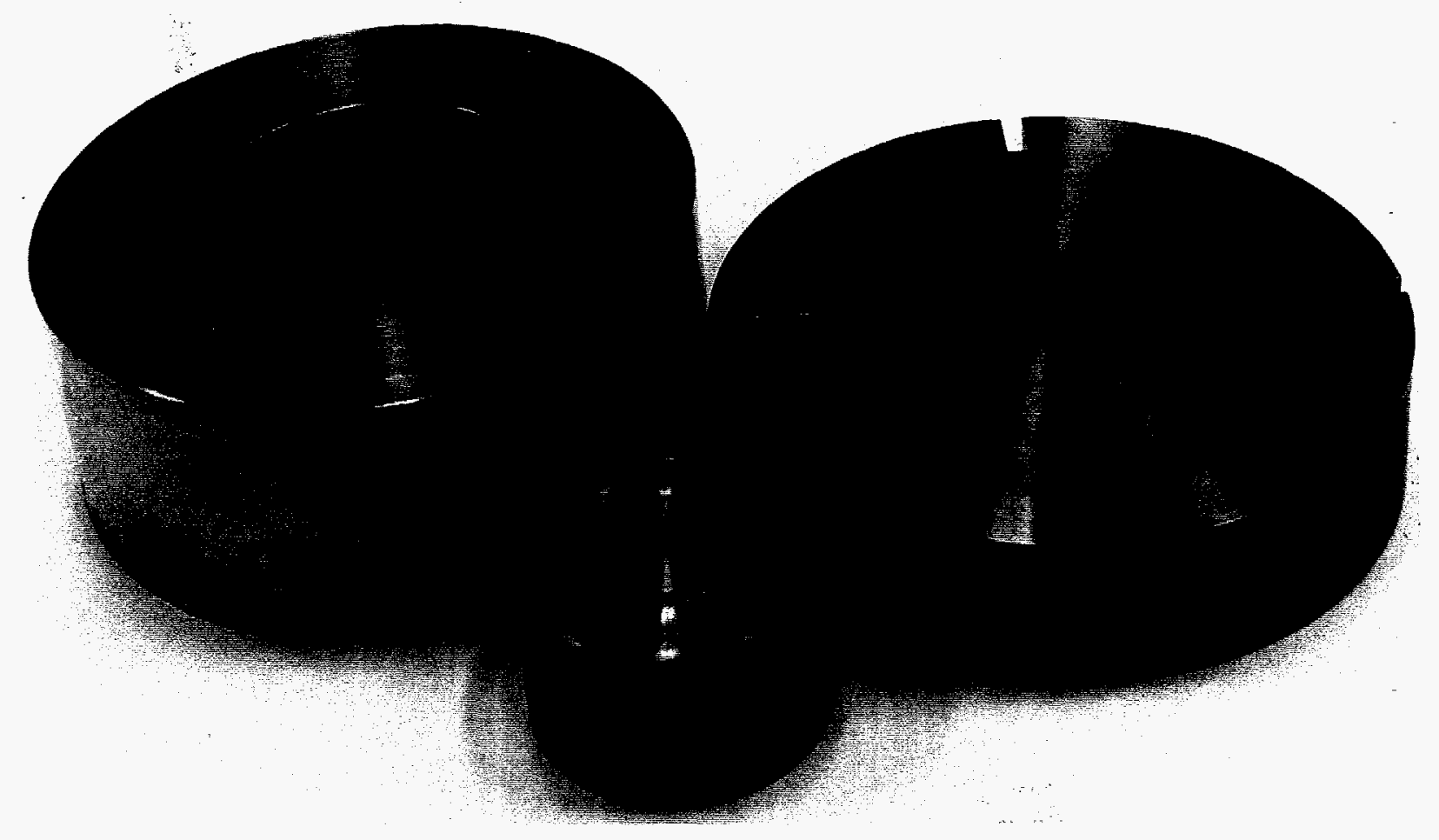

Figure 6. Photograph of fixtures for plug weld. EE54198-A, 0.5x. 


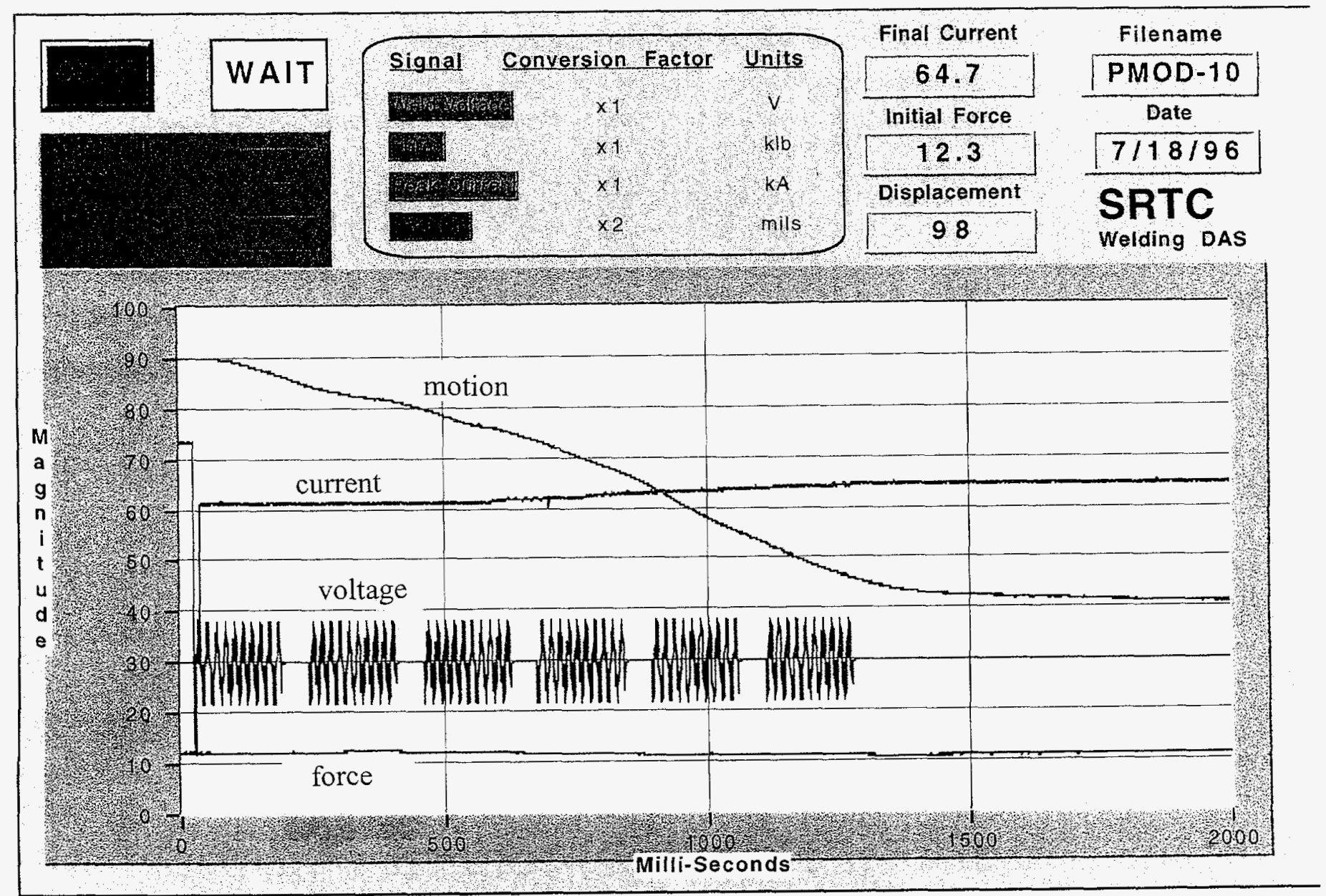

Figure 7. Data acquisition of weld parameters during weld. 


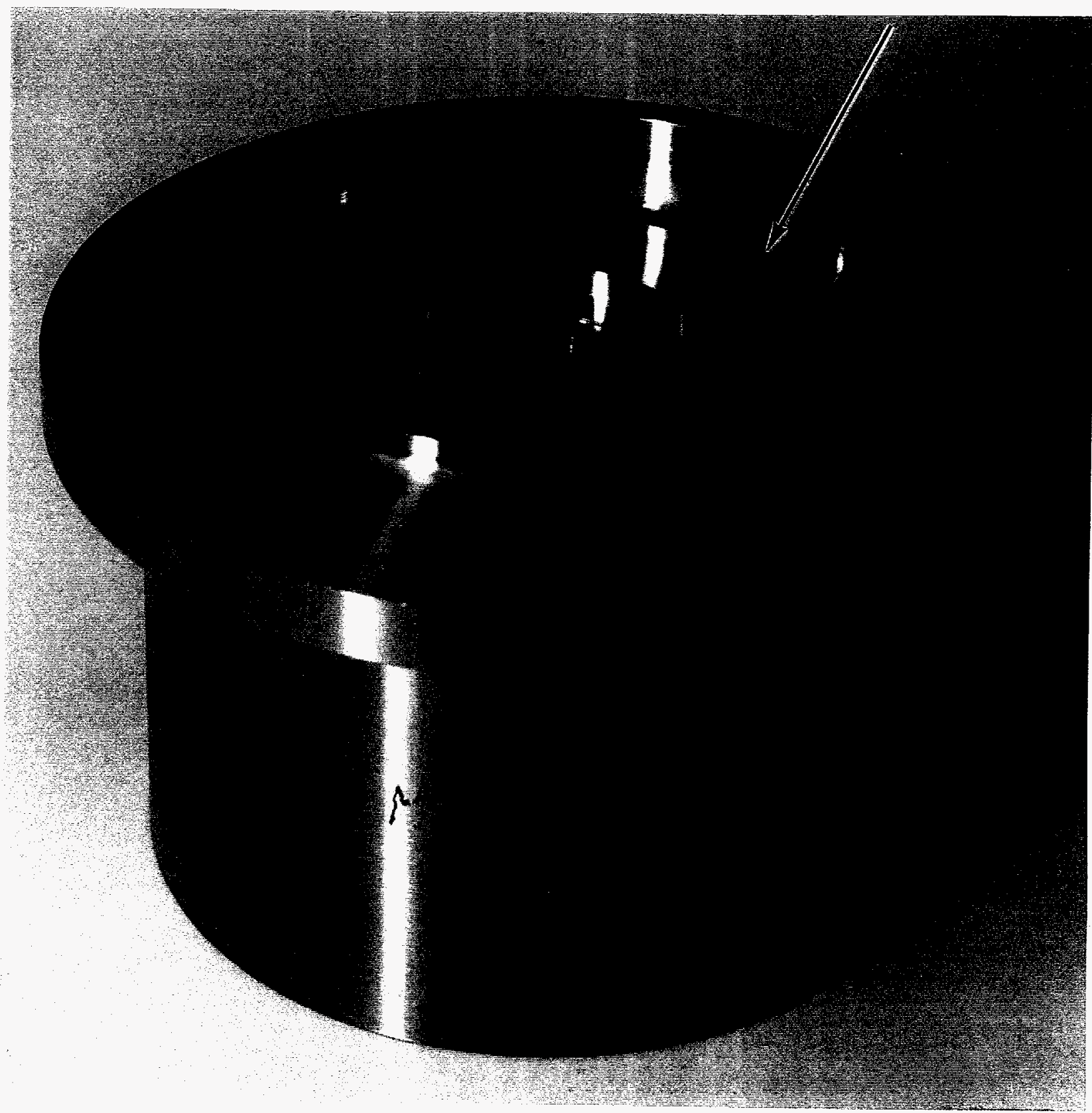

Figure 8. Photograph of sample as-welded. Weld is dark ring at arrow (this weld was made in air, resulting in oxidation at the weld joint). EE54188-A, 1.5x. 


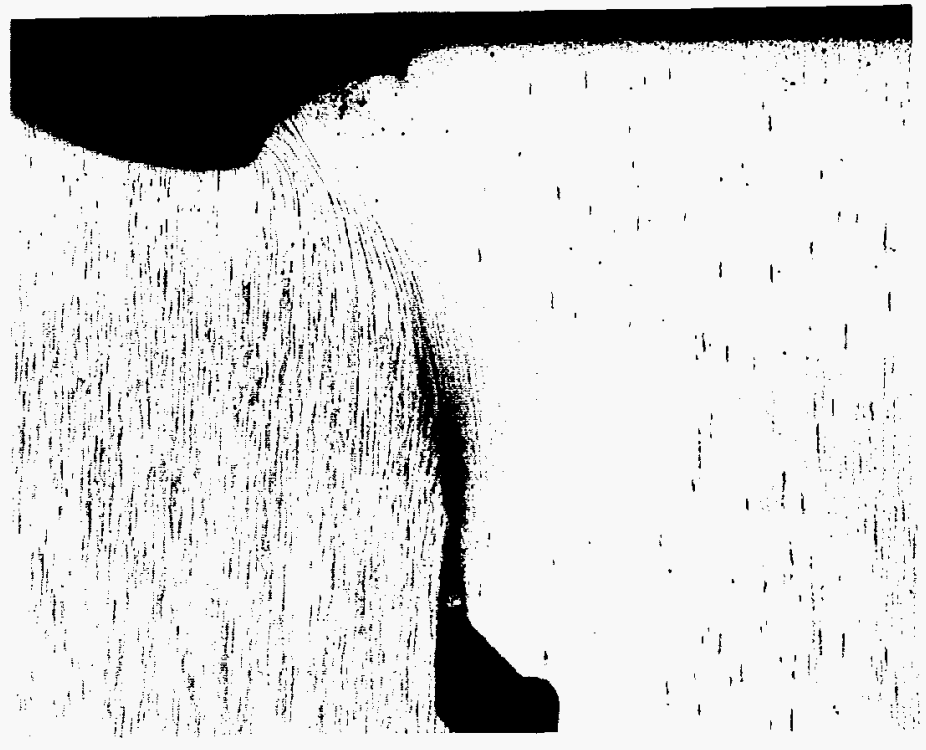

A. Weld with 0.020 inch interference (PMOD-1A-01). EE54312-A, 10x.

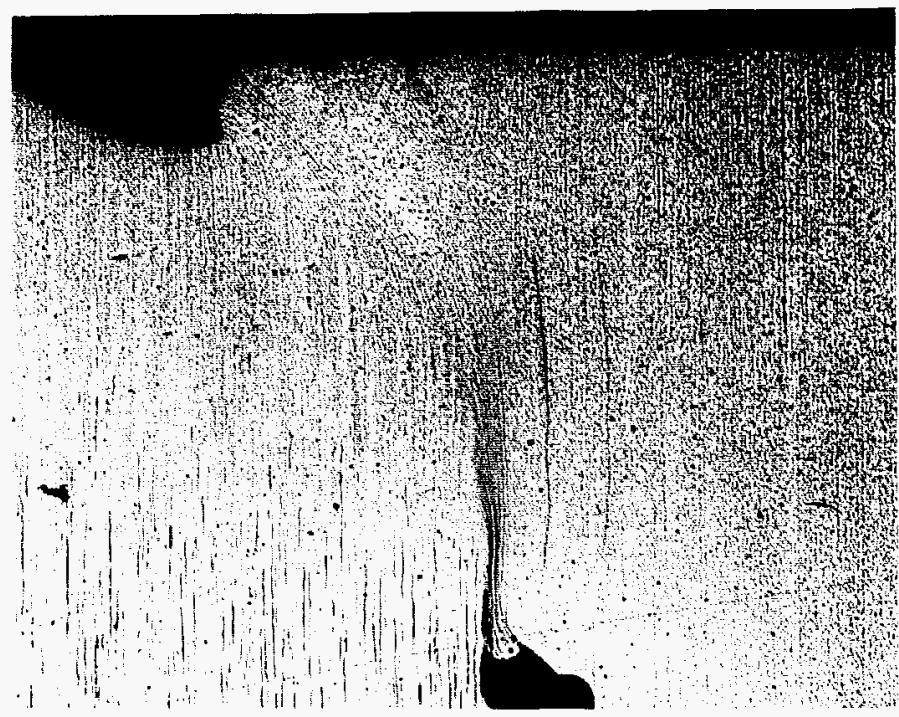

B. Weld with 0.040 inch interference (PMOD-IA-05). EE54317-A, 10x

Figure 9. Low magnification micrographs of sections of plug welds. 


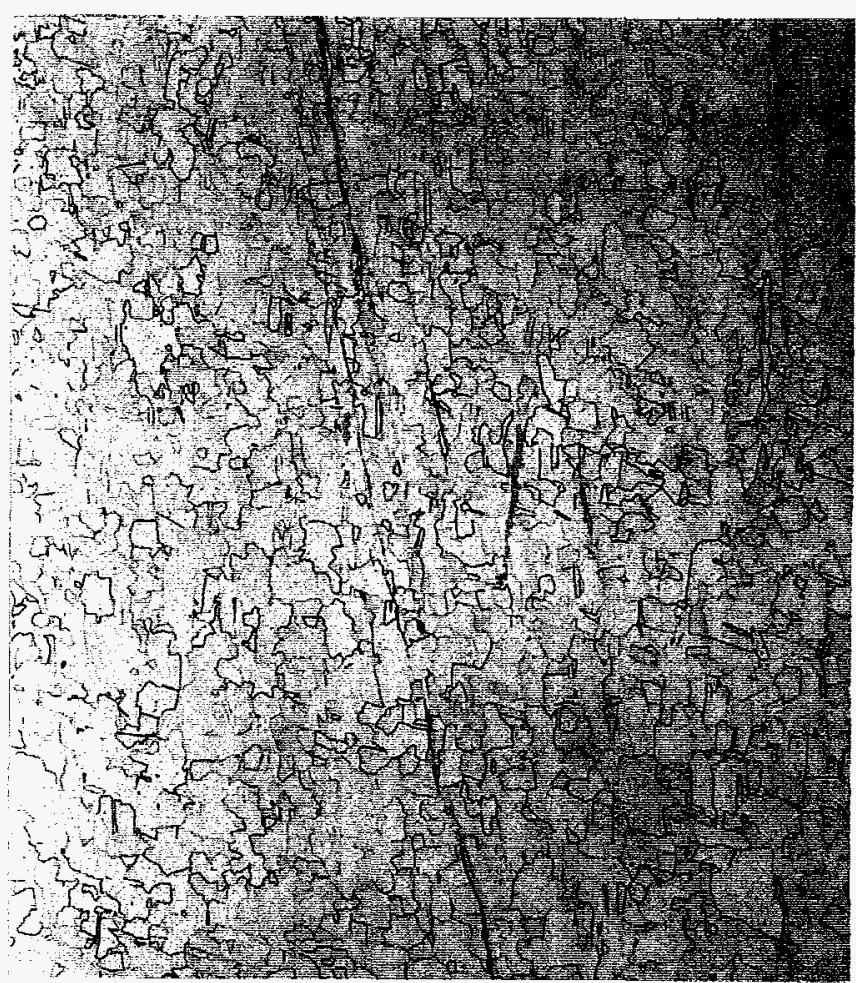

A. Weld with 0.020 inch interference (PMOD-1A-01). EE54194-A, 200x.

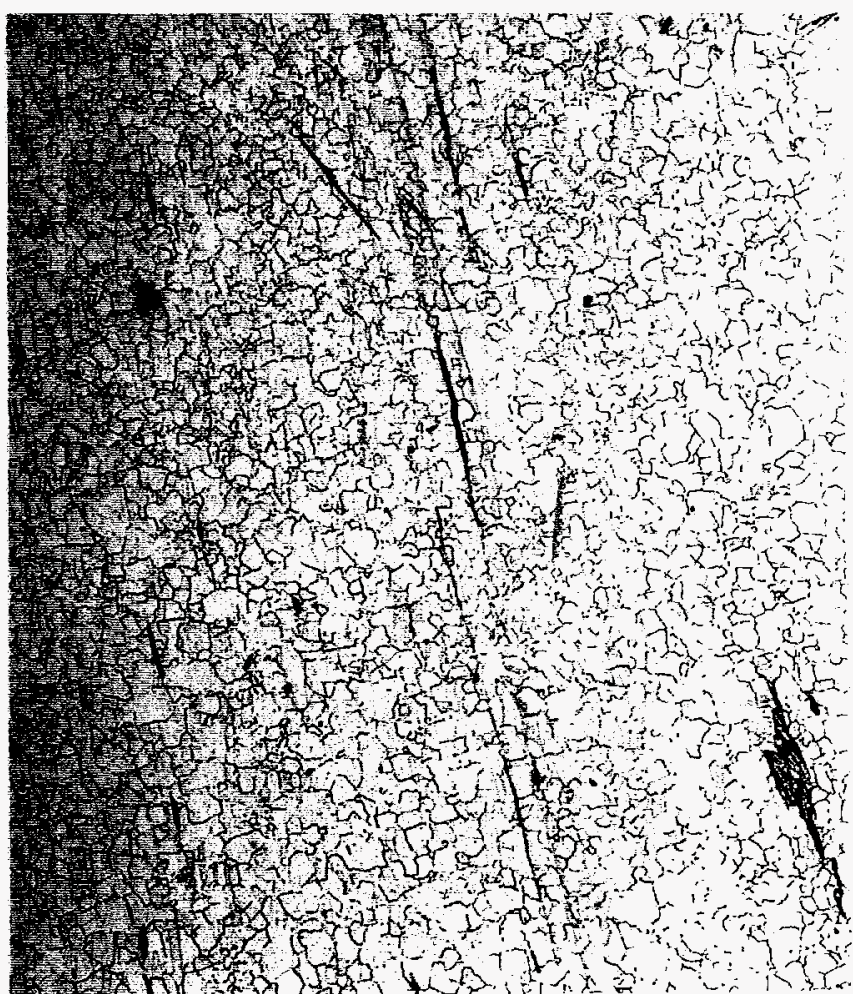

B. Weld with 0.040 inch interference (PMOD-1A-05). EE54248-A, 200x.

Figure 10. High magnification of weld joint in center of welds shown in Fig. 9. 


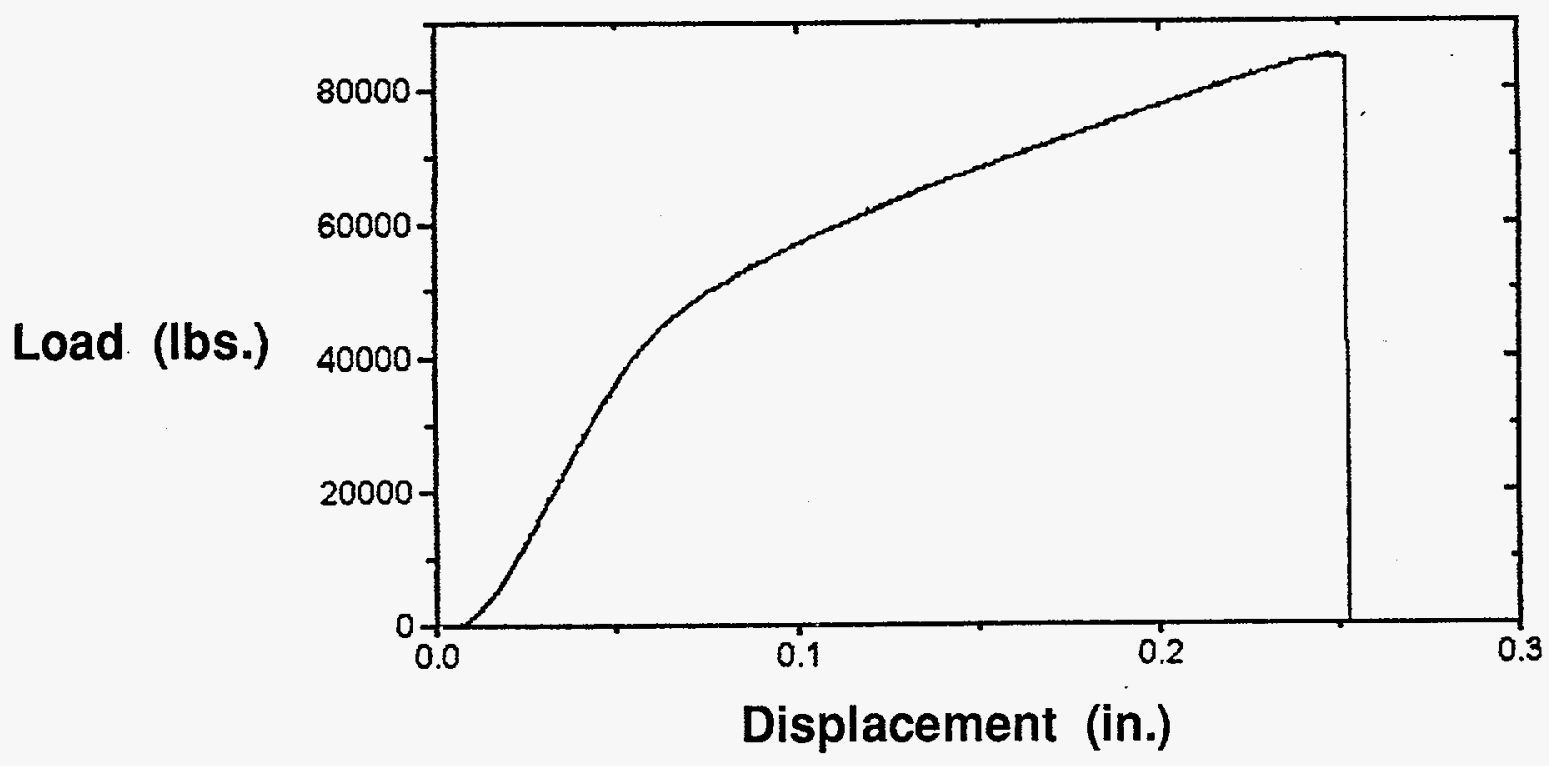

A. Load vs. displacement curve

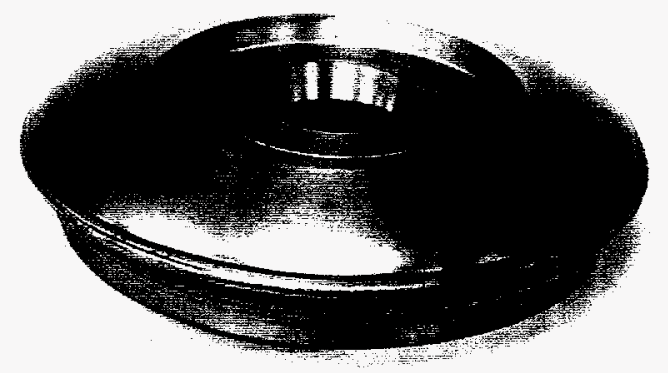

B. Puck after test. Note domed configuration after test. EE54652-A, 1x.

Figure 11. Compression tests of welds taken to failure. 


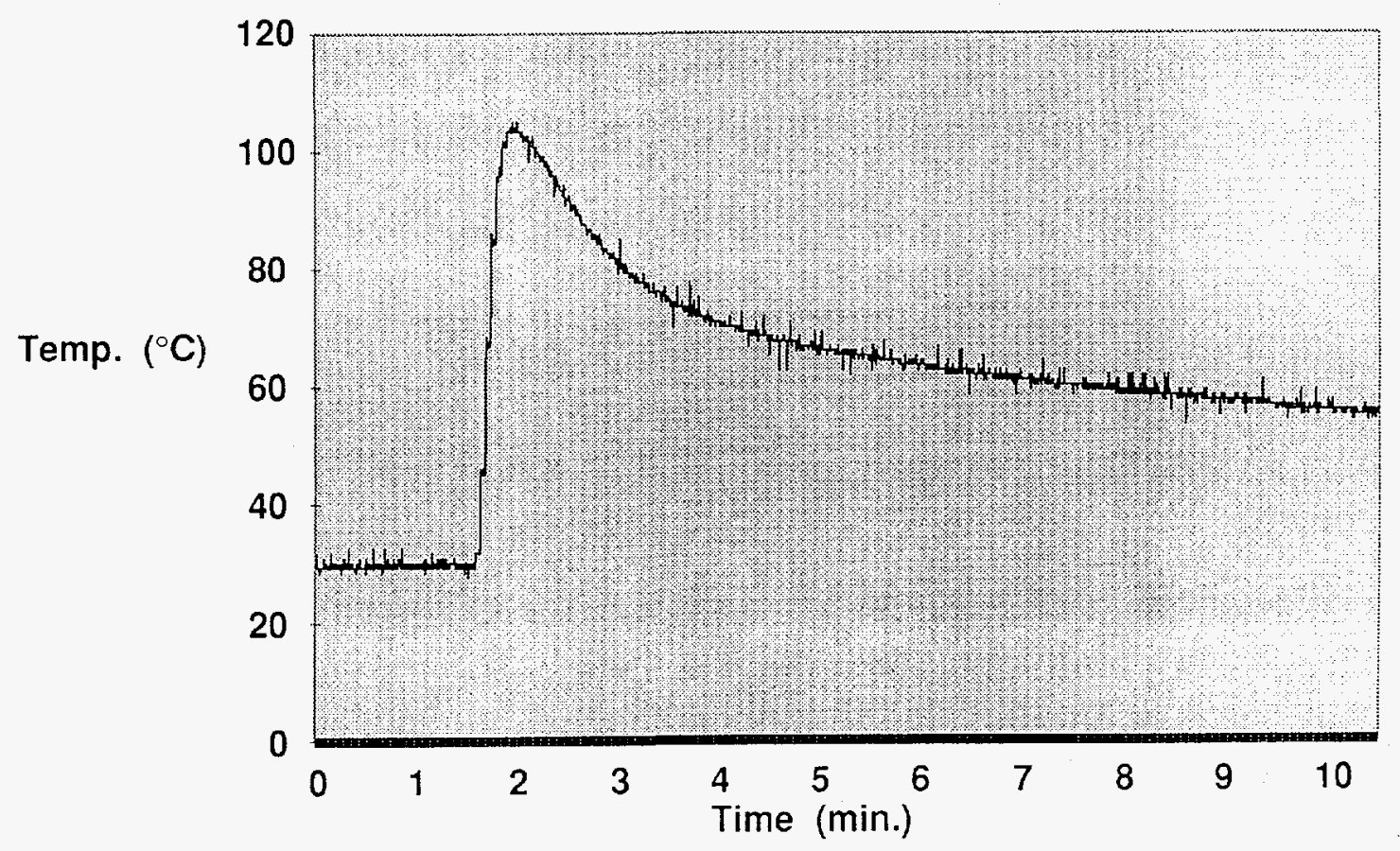

Figure 12. Temperature of chamber wall below the weld. The thermocouple was located where the bottom of the puck extender would be positioned in an actual vessel. Note that the weld is one second duration and that the time scale in this chart is in minutes. 